\title{
A Study on Chinese-English Translation of International Publicity of the Northern Shaanxi Tourism in China from the Perspective of Reception Aesthetics
}

\author{
Yizhe Tan, Xianrong Qiao, Yue Ma \\ School of Arts and Sciences, Shaanxi University of Science and Technology, Xi'an, China \\ Email: 530889163@qq.com
}

How to cite this paper: Tan, Y. Z., Qiao, X. R., \& Ma, Y. (2021). A Study on Chinese-English Translation of International Publicity of the Northern Shaanxi Tourism in China from the Perspective of Reception Aesthetics. Open Journal of Modern Linguistics, 11, 415-423.

https://doi.org/10.4236/ojml.2021.113031

Received: May 21, 2021

Accepted: June 20, 2021

Published: June 23, 2021

Copyright $\odot 2021$ by author(s) and Scientific Research Publishing Inc. This work is licensed under the Creative Commons Attribution International License (CC BY 4.0).

http://creativecommons.org/licenses/by/4.0/

\begin{abstract}
The Chinese-English translation of China's Northern Shaanxi tourism international publicity has some problems that need to discuss, which brought certain negative effects on the development of Tourism in Northern Shaanxi. From the perspective of reception aesthetics, considered comprehension and perception of foreign tourists, the current version of international publicity translation should make some modifications. As a consequence, the translation version should guide foreign tourists to understand the geographical condition and historic culture of scenic spots so as to seek the correct translation version to widely spread tourism in the Northern Shaanxi of China.
\end{abstract}

\section{Keywords}

Northern Shaanxi Tourism, International Publicity Translation, Reception Aesthetics

\section{Introduction}

According to the Statistical Bulletin of Tourism Economic Development in Shaanxi Province, China in 2019, Shaanxi Province received 3,296,200 foreign tourists in 2019 , accounting for $70.78 \%$ of inbound tourists; achieved international tourism revenue of 3.368 billion dollars, an increase of $7.72 \%$ year-over-year (due to the impact of the COVID-19 epidemic, the data of 2020 cannot treat as the reference value). It is shown that foreign markets are still the mainstay of the inbound tourism market in Shaanxi Province, China. With the deepening of the Belt and Road Initiative, tourism in cities along the route has gradually become an im- 
portant means and main direction for China to promote the economic development of countries around the world. The "13th Five-Year Plan" development goal of Shaanxi's tourism industry is to build Shaanxi into an internationally renowned and domestic first-class tourist destination by 2020. Although Shaanxi Province issued the Guidelines for English Translations in Public Places-Part 2: Tourism in 2011, the names of some tourist attractions were standardized. However, recently the author has ever traveled to some historic spots in the Northern Shaanxi and done some investigation to find that there are a large number of language errors, cultural misunderstandings and pragmatic mistakes in international publicity translation on tourism in some scenic spots in the Northern Shaanxi. The translation of Shaanxi's tourism international publicity is inaccurate, which has blocked the development of Shaanxi's tourism industry. The author sorted out sentences that have obvious errors or improper translations.

Taking full account of the comprehension and perception of foreign tourists, the problems in the translation of tourism international publicity in the Northern Shaanxi were taken as examples in this article so as to explore the enlightenment on the Chinese-English translation of tourism international publicity guided by reception aesthetics.

\section{Reception Aesthetics}

Reception aesthetics, also called reception theory, originated from a literary criticism theory in the 1950s. H. R. Jauss and W. Iser are the representatives of reception aesthetics. "Expectation horizon" is an important theory in Jauss' reception aesthetics. "Expectation horizon" is the prerequisite for readers to understand the positions, viewpoints and methods of works (Jauss \& Holub, 1987). Different from Jauss, Iser paid special attention to "reception-response". $\mathrm{He}$ emphasized the relationship between readers and works in reading and reading activities, and the interaction between works and readers in reading activities. The meaning is also produced from the reading process (Zhao, 2017).

Reception aesthetics mainly expounds the relationship among authors, texts and readers, transforming the "author-centered theory" in the past literary theory into "reader-centered theory". Taking the relationship between texts and readers as the center of literary research, reception aesthetics emphasizes readers' acceptance and understanding of texts (Qiu, 2012).

The translation of tourism international publicity is used to convey information to attract tourists. In the translation practice of tourism texts, translators must consider the acceptance of the language, culture, and pragmatics of target texts for foreign tourists. An inspiration that can be gained from the reception aesthetics in the translation of tourism international publicity is: changing perspectives, converting the focus of translation research into foreign tourists. Under the guidance of reception aesthetics, through the analysis of language misconception, cultural confusion and pragmatic mistakes in the tourism international publicity in the Northern Shaanxi, it can be found some problems, such as the 
misuse of international general units, Chinglish, and the inadequate translation of culture-loaded words in the translation of tourism publicity materials in the Northern Shaanxi, etc. This paper explores the effective translation methods of red tourism spot text, to help to promote Shaanxi's publicity and build its international image.

\section{Current Status of International Publicity Translation in the Northern Shaanxi}

Shaanxi is a major touring province in China. In recent years, with the introduction of the Belt and Road Initiative, the provincial capital city Xi'an has attracted more and more tourists. The rich tourism resources of the Northern Shaanxi have also gradually entered the public eye, such as Hongshi Valley Scenic Area, Wenchang Pavilion and Red Tourism spots. In 2019, Yan'an (a city in the Northern Shaanxi) attracted 45,700 foreign tourists, a year-over-year increase of $2.01 \%$; foreign exchange income was 4.4 million dollars, a year-over-year increase of 3.04\% (Yan'an Bureau of Statistics, 2019). This is on the one hand due to the tourism policy of China, on the other hand is the result of the regional and historical status of Yan'an in China. In order to attract more foreign tourists to travel the Northern Shaanxi, the translation quality of tourism international publicity for each scenic spot should be improved.

Wen Jun summed up six major categories of tourism translation errors, including misspelling errors, grammatical errors, Chinglish, improper wording, language cumbersome, and cultural misunderstandings (Wen et al., 2002). Jia Wenbo attributed these six categories of errors to the bad habit of "Translation assimilated by the Chinese language". The root of this bad habit is that the translator ignores the cultural differences between Chinese and English, as well as the cultural psychology and aesthetic habits of the target readers (Jia, 2003). The author sorted out three problems in the translation of tourism international publicity in the Northern Shaanxi: language misconception, cultural confusion and pragmatic mistakes, which have caused some negative effects on the development of tourism in the Northern Shaanxi. The author analyzed the above-mentioned errors with specific examples based on the reception theory, and gives the corresponding suggestions for modification.

\subsection{Language Errors}

Language errors include irregular capitalization, misuse of punctuation; misspelling of words, mixed use of Chinese and English; inconsistent tense, omission of articles, misuse of singular and plural nouns; improper collocation of words, abuse of part of speech, and so on. There were four errors in the translation of international publicity in Hongshi Valley Scenic Area and Happiness Canal: misuse of symbols, omission of translation, grammatical errors and improper use of numerical units. Although such errors will not affect the understanding of the original text of English readers, they will leave tourists with a casual and im- 
precise impression, which will have a certain negative impact on the Shaanxi tourism (Li, 2019).

Case 1: from International Publicity of Hongshi Valley Scenic Area

Source Text: 华夏第一奇峡一一红石峡(又名温盘峪), 全长 2000 米, 深 68 米, 单行线景点, 游览所需时间为一个半小时左右。

Target Text: Hongshi Valley, also called Wenpan Valley. $2000 \mathrm{~m}$ in length 68 in depth. One-way scenic spot. It takes about an hour and a half.

Comparing the source and the target texts, it can be easily seen that there are two mistakes in the target text. Firstly, the ingredients of the sentence are incomplete. If the part after the comma in "Hongshi Valley, also called Wenpan Valley" is regarded as an apposition, then the sentence lacks the predicate verb. Secondly, there is an omission. The target text missed the translation of “华夏第 一奇峡”, which is a specific evaluation of Hongshi Valley. Can “华夏第一奇峡” be literally translated into "the most strange valley in China"? Of course not. The word “奇” means "good or wonderful" here, so it is more appropriate to translate it as "outstanding". Because the low-key statements are often used in English, so the exaggerated modification of “第一” can be omitted directly. Therefore, the first sentence can be modified to "Hongshi Valley, a Chinese outstanding valley, is also called Wenpan Valley".

There is a grammatical error in the translation of the second sentence. "2000 $\mathrm{m}$ in length 68 in depth. One-way scenic spot" are not complete sentences. Corresponding to international English standards, English sentences usually have a "subject-predicate" structure. Therefore, the author proposes to add a predicate and amend Case 1 to "Hongshi Valley is a one-way scenic spot with 2000 meters in length and 68 meters in depth. It takes about an hour and a half."

Case 2: from International Publicity of Xingfu Canal

Source Text: 1940 年 4 月 29 日, 由边区建设厅工程师丁仲文设计，群众集 资与政府资助修筑的裴庄渠建成并正式放水。渠长 6 公里, 可灌溉苯园周围 五个村庄 1400 亩地, 水渠修成后, 使靠天吃饭的旱地变成了水浇地, 庄稼连 年丰收, 给群众带来了幸福生活, 因此, 群众称它为“幸福渠”。

Target Text: On April 29, 1940, Peizhuang Canal designed by Ding Zhongwen, an engineer of department of construction of the border region and funded by poll resource and government aid was finished and put to use. It was $6 \mathrm{~km}$ long and could irrigate farmland of $1400 \mathrm{mu}$ of 5 villages around Zaoyuan, on completion. Non-irrigate farmland became irrigated. And harvest was good since then. Therefore, locals called it canal of happiness.

First of all, 4 verbs are used consecutively in the first sentence of the target text. The sentence is too long with too much information. It can be seen that the translator translated the sentence word by word according to the Chinese expression, which may make foreign tourists confused. For example, “建成并正式 放水” was translated into “was finished and put to use". Actually in English, “was finished” can be omitted. “建成并正式放水” can directly be translated as "put to use". It can also reduce verbs by transforming parts of speech. It is rec- 
ommended to modify the first part of Case 2 as "On April 29, 1940, Peizhuang Canal designed by Ding Zhongwen, an engineer of department of construction of the Shaanxi-Gansu-Ningxia Border Area was put to use through the crowdfunding and government funds".

In addition, in the source text, “亩” is directly translated as “mu”. “亩” is a Chinese municipal land area unit, which is not universal in the world. Foreign tourists may not understand "mu". Therefore, it is necessary to add the international common unit "hectares" in brackets. For example, the second part of Case 2 should be modified as "It was $6 \mathrm{~km}$ long and could irrigate farmland of 1400 $\mathrm{mu}$ (93.33 ha) of 5 villages around Zaoyuan, on completion. Non-irrigate farmland became irrigated and harvest was good since then. Therefore, locals called it Canal of Happiness (or Xingfu Canal)".

Language errors do not seem to have much impact on foreign tourists' understanding of the full text, but they can reveal the translator's ability and attitude when translating. These language errors will leave bad impression of Shaanxi on foreign tourists, hinder the development of Shaanxi tourism, and ultimately may damage the image of the whole country. Such language errors cannot be ignored. As long as the translator regards translates and proofreads seriously, these language errors can be completely avoided.

\subsection{Cultural Errors}

There are often historical events, allusions of characters, myths and legends, famous sayings and other content in tourism international publicity. Such information generally exists in the cognitive context of domestic tourists. They will understand the connotation at a glance, but it is unfamiliar to foreign tourists. After reading it, they are often confused and incomprehensible. Therefore, it is necessary to grasp the initiative of the reader in translation, so that the translator and the reader can merge with each other in view (Hong, 2006). In this way, they require translators to use concise and clear language to supplement the cultural connotation contained in the publicity text through annotations.

Case 3: from International Publicity of Wenchang Pavilion

Source Text: 建于明万历年间, 二层走马楼。文昌, 本指紫薇垣中的六颗 星, 古人视为神作星辰。

Target Text: As a two-storey cloister pavilion, it was built during the reign of Emperor Wanli in Ming Dynasty. Originally, "Wenchang" represented the six stars in Ziwei, and the ancients regarded them as the Holy Stars.

First of all, the translator should supplement A.D.1572-1620 to the Ming Wanli period. Foreign tourists know little about Chinese historical dynasties and the specific year can help tourists understand when the Wenchang Pavilion was built, which give an impression of the long history of China. Secondly, the translation of “走马楼” and “紫微垣” are ignored in the target text. The author searched the related papers and found that the “走马楼” refers to the buildings with corridors all around, but "cloister" in the Oxford Advanced Learner's Eng- 
lish-Chinese Dictionary (8th edition) means a covered passage with arches around a square garden, usually forming part of a cathedral, convent or monastery. Therefore, the author suggests to transliterate “走马楼” first, and add a note, for example "Zoumalou (an ancient building in China, which has corridors in all sides)”. “紫微垣” is also not translated, either. It is not enough to just transliterate "Ziweiyuan". Foreign tourists do not know that "Ziwei" belongs to the ancient Chinese astronomy, so it is recommended to translate “紫微垣” as "Ziweiyuan (its location is close to circumpolar region according to the ancient Chinese astronomy and constellations)". Therefore, the whole sentence of Case 3 should be modified as: as a two-storey Zoumalou (an ancient building in China, which has corridors in all sides), it was built during the reign of Emperor Wanli in Ming Dynasty (A.D.1572-1620). Originally, "Wenchang" represented the six stars in Ziweiyuan (its location is close to circumpolar region according to the ancient Chinese astronomy and constellations), and the ancients regarded them as the Holy Stars.

The paraphrase briefly explains the meaning of culture-loaded words in the source language, which not only preserves the cultural characteristics of Chinese, but also introduces Chinese customs to English readers (Zhang, 2020). Transliteration is one of the most common methods for translating culture-loaded words (Zheng, 2016). However, using only transliteration often makes it difficult for foreign tourists to understand, so paraphrases can better help them understand Chinese culture. The translator decides whether to use literal translation, free translation, paraphrase or transliteration in translating culture-loaded words. Considering the degrees of foreign tourists' understanding of Chinese culture, the word should be interpreted when translating culture-loaded words. With the spread of Chinese culture to the outside world, transliteration of culturally loaded words should be taken into account when translating culture-loaded words. In summary, the author believes that the transliteration plus paraphrase is the most appropriate method for translating culture-loaded words.

\subsection{Pragmatic Errors}

In recent years, due to the development of the cities along the route of One Belt and One Road, Shaanxi's tourism industry has flourished. Because the Red Tourism culture in Shaanxi province is unique in China, the international publicity of Red Tourism has become more important. Most of the introduction to the Red Tourism scenic spots are centered on patriotism with strong political complexion. The translation version on the scenic spots is read by not only domestic tourists, but also foreign tourists with different cultural backgrounds who have little knowledge of the Red Tourism culture. Therefore, translator must consider the acceptance of foreign tourists when translating the introduction of the Red Tourism scenic spots. They should translate selectively instead all the contents word by word.

Case 4: from International Publicity of Wangjiaping-Former Revolutionary 
Sites of CPC

Source Text: 中央军委和八路军总部在这里指挥部署了敌后根据地军民的 八年抗战。抗日战争胜利后, 粉碎了国民党军队发动的“全面进攻”, 并为挫 败其“重点进攻”作了充分准备。

Target Text: Here, the Military Committee of the Party central Committee and Headquarters of the 8th Route Army led the army and people of the Shanganning border region and other Anti-Japanese base area to hold high the banner of patriotism to stuck the strategy and tactics of people's warfare, won the great victory of the Anti-Japanese war and crashed the all round attack of the KMT troops on the Liberated Areas when the Civil War broke out.

Foreign tourists are more sensitive to these words, such as Anti-Japanese, which may cause misunderstandings. It is recommended to modify it to the neutral words, such as "resistance against Japan" or "against Japanese aggression/invasion". This kind of translation error may cause communication barriers, and in some serious situations, it may also cause certain conflict issues, such as ethnic and religious problems, which will eventually damage the image of the country.

Tourism international publicity translation must cross the historical and cultural differences of multiple nationalities and grasp different national psychology (Jia, 2003). If the principle of "keeping domestic information from foreigners" is not followed before translation, and the original text is not filtered and translate the whole passage, it may cause pragmatic errors (Thomas, 1983). The main purpose of domestic tourists travelling to the red scenic spots is mainly for the revolutionary education. Chinese introduction pays more attention to the inspiring function; while foreign tourists come to China to visit the Red Tourism scenic spots mainly for learning about China's history and culture. English introduction should focus more on the informative function of the text (Tian, 2016).

In the Red Tourism spots, there are many translations with revolutionary education like "hold high the banner of patriotism to stuck the strategy (高举爱 国主义旗帜)” and “great victory (伟大胜利)”, which are not suitable for tourism international publicity. The main purpose of foreign tourists visiting the Red Tourism scenic spots is to know the historical events and stories, not to receive the education of the Chinese revolution. Therefore, in the process of Chinese-English translation of the introduction of Red Tourism scenic spots, the translator should consider the purpose and interest of foreign tourists to visit the Red Tourism scenic spots, strengthening the transmission of historical information and diluting political preaching (Liao \& Yang, 2009). Therefore, the translator can make translation of selected passage when necessary. The author suggests to modify Case 4 as "Here, the Military Committee of the Party Central Committee and Headquarters of the 8th Route Army led the army and people of the Shaanxi-Gansu-Ningxia Border Area and other base area to won the resistance against Japan with their patriotism that supported them". 


\section{Conclusion}

The Northern Shaanxi Region is rich in tourism resources, with numerous natural and cultural landscapes, as well as the unique Red Tourism scenic spots. Applying reception aesthetics to the translation, the translator should comprehensively consider the reading habits and acceptance of foreign tourists. When translating the tourism international publicity of Northern Shaanxi with rich content and unique aesthetic characteristics, the translator should try their best to keep Chinese cultural information in the source text and promote Chinese culture as much as possible. It is not necessary to translate word by word according to the Chinese expression. For culture-loaded words, the transliteration plus paraphrase can be adopted.

The English translations of the above three types of tourism international publicity in Northern Shaanxi reflect not only superficial problems, but also deep-seated reasons. The author summarizes that from the perspective of the translator, it can be divided into two points. The first point is the attitude of the translator. Many simple language errors can be found in the review and avoided in draft. The second point is the ability of the translator. The translator's inadequate language ability leads to Chinglish and inaccurate word selection. Some translators even lack the cultural knowledge of their own country, let alone convey the cultural image of their own country.

\section{Conflicts of Interest}

The authors declare no conflicts of interest regarding the publication of this paper.

\section{References}

Hong, M. (2006). On Reception Aesthetics and Concern for the TL Readers in Tourism Advertising Translation. Foreign Languages and Their Teaching, No. 8, 56-59+65.

Jauss, H. R., \& Holub, R. C. (1987). Reception Aesthetics and Reception Theory. Zhou Ning, Translator. Shenyang: Liaoning People's Publishing House.

Jia, W. B. (2003). Tourism Translation Should Not Ignore the Differences of National Aesthetic. Shanghai Journal of Translators, No. 1, 20-22.

Li, X. P. (2019). A Survey of the Existing Problems in the Translation of Publicity Materials and Public Signs in Yulin City and the Countermeasures. Journal of Yulin University, No. 1, 77-83.

Liao, Y. B., \& Yang, Y. B. (2009). Study on the Chinese-English Translation of Introduction of Red Tourist Attractions. Times Literature, No. 22, 28.

Qiu, L. (2012). On Ku Hung-Ming's English Versions of “The Discourses and Sayings of Confucius" and "The Universal Order or Conduct of Life" from the Perspective of Reception Aesthetics. Shaanxi Education, No. 7, 10-11+17.

Tian, L. (2016). Translation Strategies of Yan'an Red Tourism Texts. Journal of Yan'an University (Social Sciences Edition), No. 8, 98-102.

Thomas, J. (1983). Cross-Cultural Pragmatic Failures. Applied Linguistics, 4, 91-112. https://doi.org/10.1093/applin/4.2.91 
Wen, J., Deng, C., \& Jiang, Y. J. (2002). The Unification of Information and Acceptability-A Survey and Analysis of Current Tourism Translation. Chinese Science \& Technology Translators Journal, No. 1, 49-52+64.

Yan'an Bureau of Statistics (2019). Statistical Bulletin of National Economy and Social Development in Yan'an in 2019. http://tjj.shaanxi.gov.cn/tjsj/ndsj/tjgb/gs/202011/t20201109_2005045.html

Zhang, H. Y. (2020). On the Translation of Culturally Loaded Words in "A Dream of Red Mansions". Journal of Anhui University (Philosophy and Social Sciences Edition), No. 4, 60-63.

Zhao, C. (2017). Viewing Reception Aesthetics from Jauss and Isel. Chinese \& Foreign Entrepreneurs, No. 3, 259-260.

Zheng, D. H. (2016). Chinese Culture Going Out and the Translation of Culture-Loaded Words. Shanghai Journal of Translators, No. 2, 53-56. 